\title{
Phytogeographical patterns of Crotalaria SPeCies (Leguminosae-PapiLIONOIDEAE) In BRAZIL
}

\author{
Andréia S. Flores ${ }^{1,3}$ \& Ana Maria G. Azevedo Tozzi $i^{2}$
}

\begin{abstract}
(Phytogeographical patterns of Crotalaria L. species (Leguminosae-Papilionoideae) in Brazil) The phytogeography and preferred habitat of Crotalaria species from Brazil are studied. Four species are widely distributed in Brazil, while C. goiasensis and C. irwinii are endemic to the state of Goiás, C. clausseni to São Paulo, C. rufipila to Minas Gerais and C. brachycarpa and C. harleyi to Bahia. Crotalaria species occurs in the following biogeographical provinces: Amazonian, Atlantic, Caatinga, Cerrado, Chaqueña, Guayana, Pampeana and Paranaense. The Cerrado province presents the largest number of species with restricted distribution, followed by the Paranaense province. The geographical distribution of species in Brazil shows higher species diversity in the highlands $(800$ - 2000 m.s.m.), such as the Serra Geral de Goiás, Chapada dos Veadeiros, Espinhaço Range (15-16 spp.), Serra da Mantiqueira and Serra do Mar (14 spp.). As well as the altitude, vegetation and climate influence the distribution of Crotalaria in Brazil.
\end{abstract}

Key words: cerrado, Papilionaceae, endemism, highlands, preferred habitat, biogeographical provinces.

Resumo

(Padrões fitogeográficos das espécies de Crotalaria L. (Leguminosae-Papilionoideae) no Brasil) Este estudo apresenta a fitogeografia e os hábitos preferenciais das espécies de Crotalaria no Brasil. Quatro espécies são amplamente distribuídas no Brasil. Por outro lado, $C$. goiasensis e $C$. irwinii são endêmicas de Goiás, $C$. clausseni de São Paulo, C. rufipila de Minas Gerais e C. brachycarpa e C. harleyi da Bahia. As espécies de Crotalaria ocorrem nas seguintes províncias biogeográficas: cerrado, paranense, atlântica, amazônica, caatinga, chaquenha, guayana e pampeana. A província do cerrado apresenta o maior número de espécies exclusivas seguida da província paranense. A distribuição geográfica das espécies brasileiras mostra que a maior diversidade ocorre em áreas elevadas ( 800 - 2000 m.s.m.), como a Serra Geral de Goiás, Chapada dos Veadeiros, Cadeia do Espinhaço (15-16 spp.), Serra da Mantiqueira e Serra do Mar (14 spp.). As elevadas altitudes, bem como as características vegetacionais e climáticas influenciam a distribuição das espécies de Crotalaria no Brasil.

Palavras-chave: cerrado, endemismos, altitudes elevadas, hábito preferencial, províncias biogeográficas.

\section{INTRODUCTION}

The genus Crotalaria L. is considered to be the third largest genus of Papilionoideae, with around 600 species distributed throughout the tropics and subtropics (Polhill 1982). The Neotropics has approximately 70 species occurring from southern United States to subtropical Argentina and Uruguay (Lewis 1987; Polhill et al. 2001). The centers of diversity of the genus are eastern and southern tropical Africa and India, with two additional centers in Mexico and Brazil (Palomino \& Vásquez 1991).

Crotalaria comprises herbaceous and shrubby species with simple, unifoliolate or digitately 3-(4-5)-foliolate leaves, stamens monadelphous with the sheath split at least at the very base, dimorphic anthers and inflated legumes. The genus was subdivided into eight sections by Polhill (1968) and Bisby \& Polhill (1973), based on floral morphology of African species. Native species in Brazil are grouped in two sections, Crotalaria sect. Chrysocalycinae (Benth.) Baker f. and Crotalaria sect. Calycinae Wight \& Arn. (Flores 2004). These sections have a west-east distribution, the former mainly in western Africa and America tropics, and the latter extending from there to Asia, Australia and the New World (Polhill 1982).

Artigo recebido em 06/2006. Aceito para publicação em 06/2007.

${ }^{1}$ Museu Integrado de Roraima, Av. Brig. Eduardo Gomes s.n., Parque Anauá, 69305-010, Boa Vista, Roraima, Brasil. ${ }^{2}$ Universidade Estadual de Campinas, Instituto de Biologia, Departamento de Botânica, C.P. 6109, 13083-970, Campinas, SP, Brasil.

${ }^{3}$ Autor para correspondência: andreiasflores@gmail.com 
The great majority of Crotalaria species is adapted for a tropical climate and only a restricted number of species occurs in temperate regions. Crotalaria species have a wide tolerance of edaphic conditions. The majority of species have a high light requirement, therefore they are absent from forest's interior, but are relatively common in clearings and forest margins (Polhill 1968, 1982). Moreover, some species are reasonably competitive in closed herbaceous vegetation and disturbed areas, with some species, often the exotic ones, persist as weeds and are able to invade field crops.

The great diversity of climate, soil and geomorphology found in Brazil is reflected by the variety of vegetation types, making it a very interesting area for phytogeographical studies. Many authors proposed different biotic subdivisions of tropical America. Cabrera \& Willink (1980) proposed a biogeographical classification based on flora and fauna composition of Latin America, which was divided into dominions and subdivided into provinces. According to this classification, there are three dominions and nine provinces represented in Brazil.

The phytogeographical aspects of Crotalaria species were studied in southern Brazil (Flores $\&$ Miotto 2005). The present study aims to analyze the distribution and preferred habitat of the Crotalaria species from Brazil and to compare the species distribution with the biogeographical classification proposed by Cabrera \& Willink (1980).

\section{Material And Methods}

This study was based on data from the taxonomic treatment of Crotalaria (Flores 2004), obtained from analysis of herbarium specimens from ALCB, BHCB, BHMH, BM, BR, C, CEN, CEPEC, CGMS, CPAP, CTES, CVRD, FUEL, FUFMT, GH, HAS, HB, HBG, HBR, HEPA, HRCB, HUEFS, ICN, IAC, IAN, INPA, IPA, L, LP, MBM, MG, MO, NY, PACA, PEL, PEUFR, PMSP, R, RB, S, SJRP, SP, SPF, SPFR, SPSF, U, UB, UEC, US, and VIC (acrônimos segundo Holmgren et al. 1990) and extensive fieldwork in different regions of Brazil.
Distribution data of the species in extra Brazilian areas were obtained from literature.

The distribution of Brazilian Crotalaria species was plotted in maps (modified from Flora Neotropica monographs) and compared to detected patterns of species distribution with the biogeographical classification proposed by Cabrera \& Willink (1980).

\section{Results and Discussion}

No phylogenetic study is available to Crotalaria, but while it is straightforward to ascribe the origin of the genus to Africa or Asia, its evolutionary and diversification history remains unclear. For Crotalaria species from New World, cytological studies indicate that polyploidy is at the least one of the evolutionary strategies of this genus in this area, suggesting that the New World could have been the last area to be colonized by Calycinae species, with an increase in ploidy level (Flores et al. 2006).

Brazil possesses the majority of the Crotalaria species occurring in South America, with 31 native and 11 introduced or naturalized (Flores 2004). The naturalized species are native mostly to Africa and Asia; only $C$. longirostrata Hook \& Arn. is native to North and Central America. These species are found in various habitats, usually competing with the native species for the same environment, mainly the African C. lanceolata E. Mey. and C. pallida Aiton and the Asian species C. juncea L., $C$. spectabilis Roth and $C$. retusa $\mathrm{L}$. The other naturalized species are found under culture or as adventitious along the roadsides and fallow fields. Crotalaria incana is found in disturbed areas and is referred as native to Africa by Polhill (1968; 1982). However, the fact that this species was originally described from Jamaica, with its varieties distributed in Central and South America (Senn 1939; Windler et al. 1992), suggests that $C$. incana is native to the Neotropics.

Of the 31 native Crotalaria species found in Brazil, 17 are endemic, six are distributed in South America and eight are widespread throughout the Neotropics. These species are 
mainly found in open areas of savannas, 'campo rupestre' and 'restinga' vegetation, as well as along margins of gallery forests (Table 1). The recently described $C$. miottoae (Flores \& Tozzi 2005 ) is the only species that occurs in the interior of altitudinal forests, an unusual habitat for the genus.

According to Cabrera \& Willink (1980), in Brazil the Amazonian Dominion is represented by four phytogeographic provinces (Amazonian, Cerrado, Paranaense, and Atlantic), Guayana Dominion is represented only by the Guayana province, and the Chaqueña Dominion by four provinces: Caatinga, Chaqueña, Espinal, and Pampeana (Fig. 1). There are records of the occurrence of Crotalaria species in all of these biogeographical provinces, except in the Espinal (Table 2). The species $C$. stipularia, $C$. maypurensis, C. incana and C. micans (Fig. 2 ) are widespread throughout six or seven provinces (Table 2). On the other hand, 12 species are restricted to one province (Fig. 3), some of them with a very restricted distribution probably representing micro-endemism in Cerrado, Atlantic or Caatinga provinces (Fig. 4).

The Amazonian Dominion is the largest one in Brazil, where the Leguminosae are considered the most important family because of their representativity in terms of the floristic composition. The Guayana Dominion has a low proportion in Brazil, occupying highlands above $2,000 \mathrm{~m}$ in the extreme North, between $0^{\circ}$ and $4^{\circ} \mathrm{N}$. Its flora is considered similar with the one of the Cerrado province and the montane areas of southern Brazil, but shows a high degree of endemism of family and genera (Cabrera \& Willink 1980). In Brazil, the Guayana Dominion has an annual precipitation from 1,100 to $2,000 \mathrm{~mm}$ and a mean annual temperature from 16 to $25^{\circ} \mathrm{C}$, with a pronounced dry season from December to February.

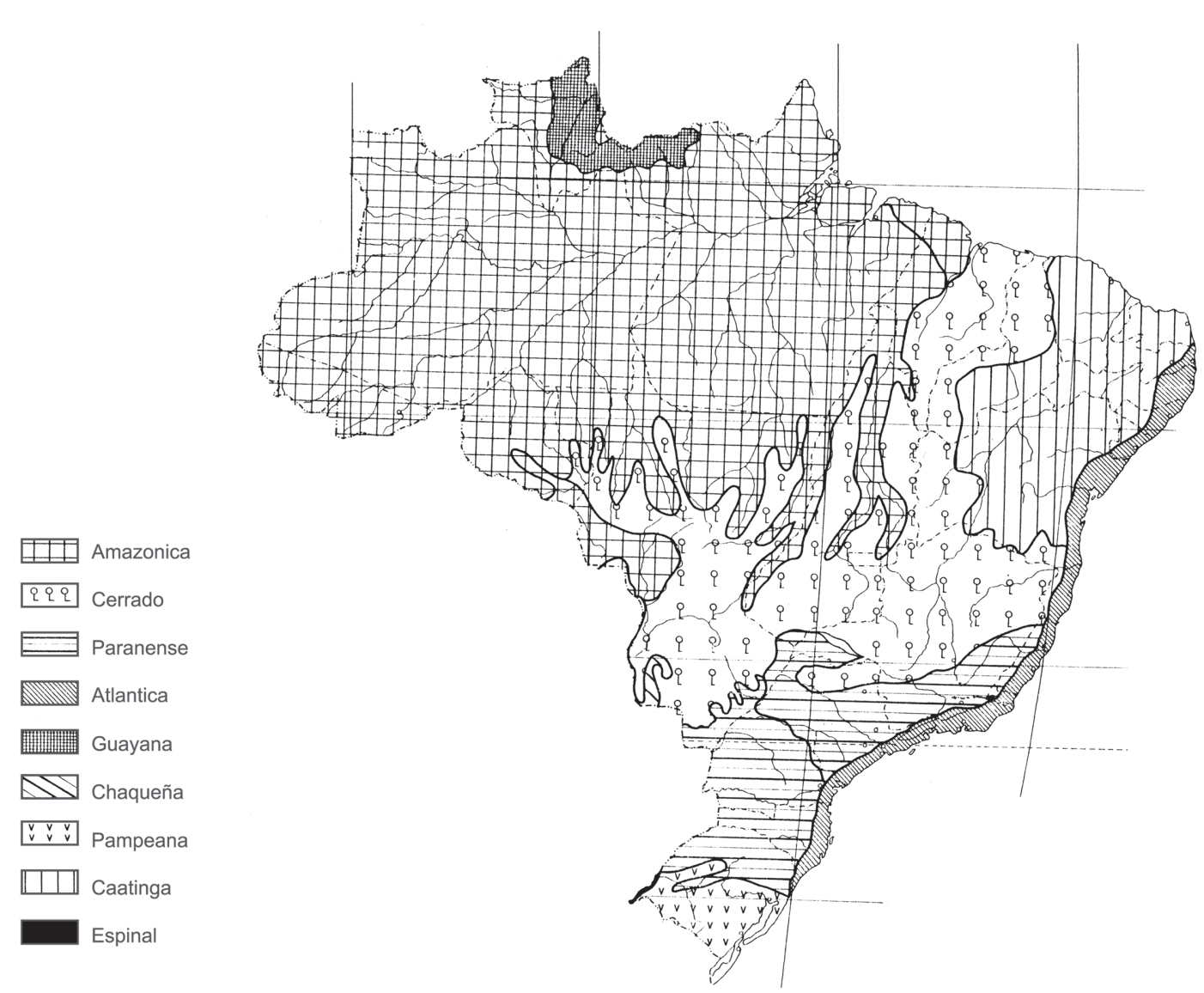

Figure 1 - Dominions and provinces represented in Brazil according to Cabrera \& Willink (1980). (Modified map of Cabrera \& Willink 1980). 
Table 1 - Geographical distribution, preferred habitats and frequency of collections of Brazilian Crotalaria species. ARG: Argentina; BRA: Brazil, COL: Colombia; PAR: Paraguay; URU: Uruguay; VEN: Venezuela; NEOTR: Neotropics. Frequency of collections: very rare: 1-3 registers; rare: 410; occasional: 11-20; common: over 20 registers.

\begin{tabular}{|c|c|c|c|}
\hline Species & DISTRIBUTION & $\begin{array}{l}\text { PREFERRED } \\
\text { HABITATS }\end{array}$ & FREQUENCY \\
\hline C. bahiaensis D.R. Windler \& S.G. Skinner & BRA & grassland & occasional \\
\hline C. balansae Micheli & BRA, PAR & grassland & common \\
\hline C. brachycarpa Benth. & BRA & grassland & very rare \\
\hline C. breviflora DC. & BRA & grassland, forest margin & common \\
\hline C. clausseni Benth. & BRA & grassland & rare \\
\hline C. flavicoma Benth. & BRA & grassland & common \\
\hline C. goiasensis D.R. Windler \& S.G. Skinner & BRA & forest margin & rare \\
\hline C. grandiflora Benth. & BRA & forest margin & occasional \\
\hline C. harleyi D.R. Windler \& S.G. Skinner & BRA & grassland & occasional \\
\hline C. hilariana Benth. & BRA & grassland & common \\
\hline C. holosericea Nees \& Mart. & BRA & grassland, forest margin & common \\
\hline C. incana $\mathrm{L}$. & NEOTR & grassland, forest margin & common \\
\hline C. irwinii D.R. Windler \& S.G. Skinner & BRA & grassland & very rare \\
\hline C. laeta Mart. ex Benth. & BRA & grassland, forest margin & common \\
\hline C. martiana subsp. martiana Benth. & BRA & grassland, forest margin & common \\
\hline $\begin{array}{l}\text { C. martiana subsp. mohlenbrockii } \\
\text { (D.R. Windler \& S.G. Skinner) Planchuelo }\end{array}$ & BRA, PAR & grassland, forest margin & common \\
\hline C. maypurensis Kunth & NEOTR & grassland & common \\
\hline C. micans Link & NEOTR & grassland, forest margin & common \\
\hline C. miottoae A.S. Flores \& A.M.G. Azevedo & BRA & $\begin{array}{l}\text { grassland, forest margin } \\
\text { and understory }\end{array}$ & common \\
\hline C. nitens Kunth & NEOTR & grassland & occasional \\
\hline C. otoptera Benth. & BRA & grassland, forest margin & rare \\
\hline C. paulina Schrank & BRA, VEN & grassland, forest margin & common \\
\hline C. pilosa Mill. & NEOTR. & grassland & common \\
\hline C. rufipila Benth. & BRA & grassland, forest margin & occasional \\
\hline C. sagittallis $\mathrm{L}$. & NEOTR & grassland & occasional \\
\hline C. stipularia Desv. & NEOTR & grassland & common \\
\hline C. subdecurrens Mart. ex Benth. & BRA & forest margin & common \\
\hline C. tweediana Benth. & $\begin{array}{r}\text { BRA, URU, } \\
\text { PAR, ARG }\end{array}$ & grassland & common \\
\hline C. unifoliolata Benth. & BRA & grassland & common \\
\hline C. velutina Benth. & BRA, COL & grassland & common \\
\hline C. vespertilio Benth. & BRA, ARG & grassland, forest margin & common \\
\hline C. vitellina Ker-Gawler & NEOTR & grassland, forest margin & common \\
\hline
\end{tabular}


Table 2 - Brazilian species of Crotalaria occurring in the phytogeographical provinces proposed by Cabrera \& Willink (1980). (ESP: Espinal; PAM: Pampeana; GUA: Guayana; CHA: Chaqueña; CAA: Caatinga; AMA: Amazonian; ATL: Atlantic; PAR: Paranaense; CER: Cerrado).

\begin{tabular}{|c|c|c|c|c|c|c|c|c|c|}
\hline & ESP & PAM & GUA & CHA & CAA & AMA & ATL & PAR & CER \\
\hline C. bahiaensis D.R. Windler \& S.G. Skinner & & & & & $\mathrm{X}$ & & & & \\
\hline C. balansae Micheli & & & & & & & $\mathrm{X}$ & $\mathrm{X}$ & $\mathrm{X}$ \\
\hline C. brachycarpa Benth. & & & & & $\mathrm{X}$ & & & & \\
\hline C. breviflora DC. & & & & & & & $\mathrm{X}$ & $\mathrm{X}$ & $\mathrm{X}$ \\
\hline C. clausseni Benth. & & & & & & & $\mathrm{X}$ & & \\
\hline C. flavicoma Benth. & & & & & & & & & $\mathrm{X}$ \\
\hline C. goiasensis D.R. Windler \& S.G. Skinner & & & & & & & & & $\mathrm{X}$ \\
\hline C. grandiflora Benth. & & & & & & & & & $\mathrm{X}$ \\
\hline C. harleyi D.R. Windler \& S.G. Skinner & & & & & $\mathrm{X}$ & & & & $\mathrm{X}$ \\
\hline C. hilariana Benth. & & $\mathrm{X}$ & & & & & $\mathrm{X}$ & $\mathrm{X}$ & \\
\hline C. holosericea Nees \& Mart. & & & & & $\mathrm{X}$ & & $\mathrm{X}$ & & $\mathrm{X}$ \\
\hline C. incana $\mathrm{L}$. & & & & $\mathrm{X}$ & $\mathrm{X}$ & $\mathrm{X}$ & $\mathrm{X}$ & $\mathrm{X}$ & $\mathrm{X}$ \\
\hline C. irwinii D.R. Windler \& S.G. Skinner & & & & & & & & & $\mathrm{X}$ \\
\hline C. laeta Mart. ex Benth. & & & & $\mathrm{X}$ & $\mathrm{X}$ & & & & $\mathrm{X}$ \\
\hline C. martiana subsp. martiana Benth. & & & & & & & & & $\mathrm{X}$ \\
\hline $\begin{array}{l}\text { C. martiana subsp. mohlenbrockii } \\
\text { (D.R. Windler \& S.G. Skinner) Planchuelo }\end{array}$ & & & & & & $\mathrm{X}$ & $\mathrm{X}$ & $\mathrm{X}$ & $\mathrm{X}$ \\
\hline C. maypurensis Kunth. & & & $\mathrm{X}$ & $\mathrm{X}$ & $\mathrm{X}$ & $\mathrm{X}$ & $\mathrm{X}$ & $\mathrm{X}$ & $\mathrm{X}$ \\
\hline C. micans Link & & & $\mathrm{X}$ & & $\mathrm{X}$ & $\mathrm{X}$ & $\mathrm{X}$ & $\mathrm{X}$ & $\mathrm{X}$ \\
\hline C. miottoae A.S. Flores \& A.M.G. Azevedo & & & & & & & $\mathrm{X}$ & $\mathrm{X}$ & $\mathrm{X}$ \\
\hline C. nitens Kunth & & & & & & $\mathrm{X}$ & & & \\
\hline C. otoptera Benth. & & & & & & & & & $\mathrm{X}$ \\
\hline C. paulina Schrank & & & & & & & $\mathrm{X}$ & $\mathrm{X}$ & $\mathrm{X}$ \\
\hline C. pilosa Mill. & & & $\mathrm{X}$ & & & $\mathrm{X}$ & & $\mathrm{X}$ & $\mathrm{X}$ \\
\hline C. rufipila Benth. & & & & & & & & & $\mathrm{X}$ \\
\hline C. sagittalis $\mathrm{L}$. & & & $\mathrm{X}$ & $\mathrm{X}$ & & $\mathrm{X}$ & & & $\mathrm{X}$ \\
\hline C. stipularia Desv. & & & $\mathrm{X}$ & $\mathrm{X}$ & $\mathrm{X}$ & $\mathrm{X}$ & $\mathrm{X}$ & $\mathrm{X}$ & $\mathrm{X}$ \\
\hline C. subdecurrens Mart. ex Benth. & & & & & & & & & $\mathrm{X}$ \\
\hline C. tweediana Benth. & & $\mathrm{X}$ & & & & & & $\mathrm{X}$ & \\
\hline C. unifoliolata Benth. & & & & & & & & $\mathrm{X}$ & $\mathrm{X}$ \\
\hline C. velutina Benth. & & & & & & & $\mathrm{X}$ & $\mathrm{X}$ & $\mathrm{X}$ \\
\hline C. vespertilio Benth. & & & & & & & $\mathrm{X}$ & $\mathrm{X}$ & $\mathrm{X}$ \\
\hline C. vitellina Ker-Gawler & & & & & $\mathrm{X}$ & & $\mathrm{X}$ & $\mathrm{X}$ & $\mathrm{X}$ \\
\hline $\mathrm{n}^{\mathrm{o}} \mathrm{spp}$ total/province & 0 & 2 & 5 & 5 & 10 & 8 & 15 & 16 & 25 \\
\hline $\mathrm{n}^{\mathrm{o}}$ spp. exclusive/province & 0 & 0 & 0 & 0 & 1 & 1 & 1 & 0 & 8 \\
\hline
\end{tabular}




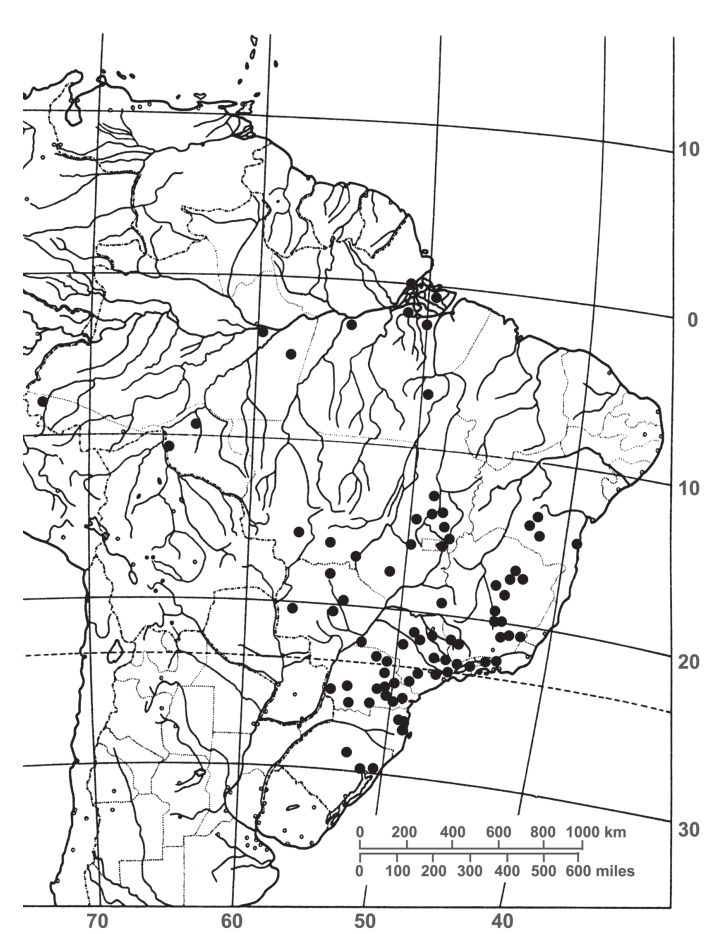

Figure 2 - Geographical distribution of Crotalaria micans.

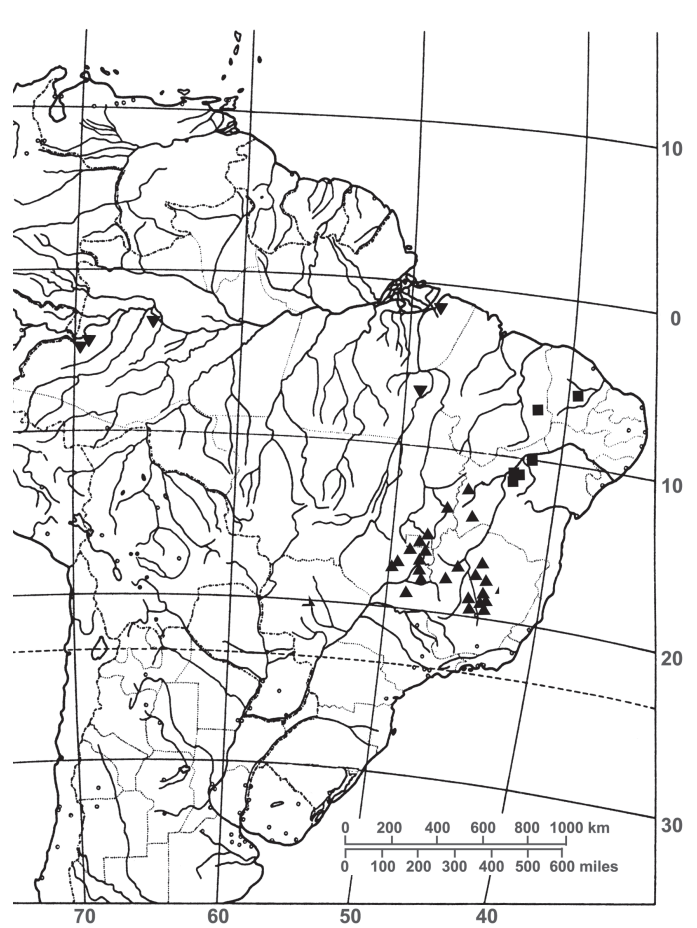

Figure 3 - Some species of Crotalaria with distribution restricted to one province in Brazil. $\boldsymbol{\Delta}$ C. flavicoma (Cerrado province), $\mathbf{C}$. bahiaensis (Caatinga province), $\checkmark$ C. nitens (Amazonian province).

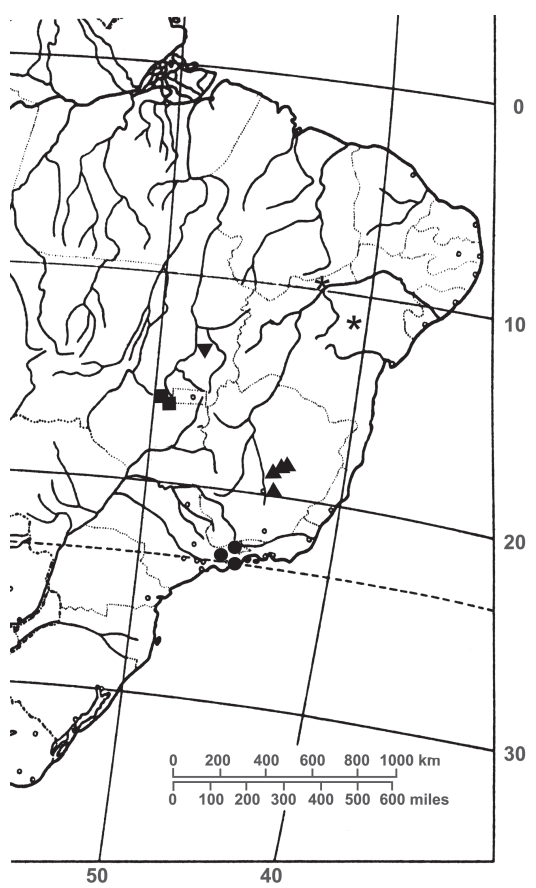

Figure 4 - Species of Crotalaria with very restricted distribution in Brazil. * C. brachycarpa, $\boldsymbol{\nabla}$ C. irwinii, C. goiasensis, $\mathbf{\Delta}$ C. rufipila, $\bigcirc$. claussenii.

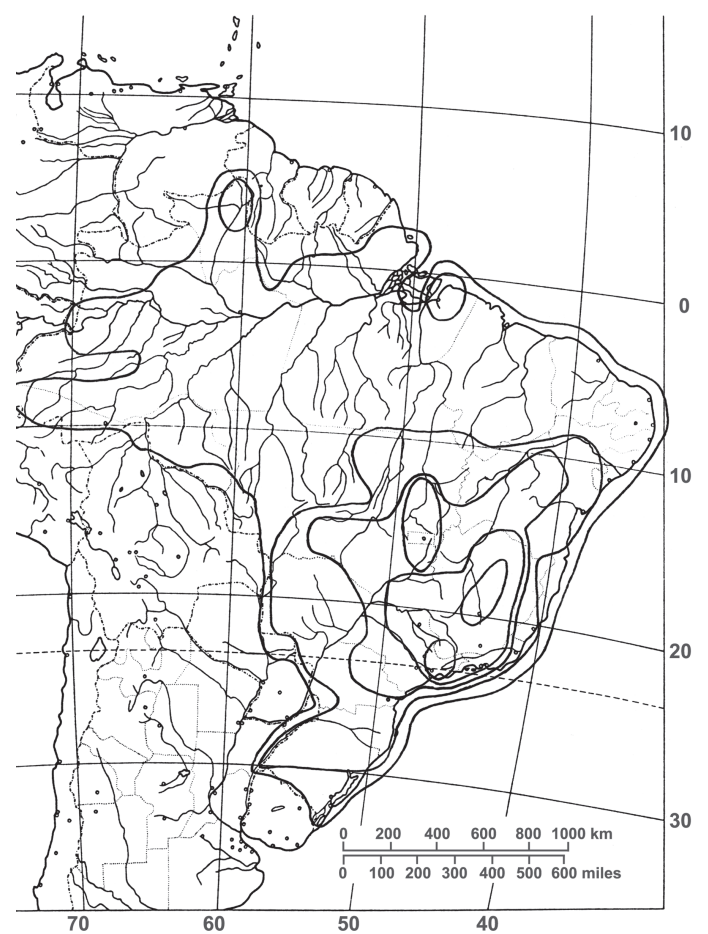

Figure 5 - Geographical distribution and centers of diversity of Crotalaria species in Brazil. a. 14-16 spp., b. 11-13 spp., c. 7-10 spp. d. 4-6 spp., e. 1-3 spp. 
The Cerrado province occupies central and eastern Brazilian regions between $3^{\circ} \mathrm{S}$ and $23^{\circ} \mathrm{S}$ with an area of approximately 2,000.000 $\mathrm{km}^{2}$. It has a great environmental diversity, with many heterogeneous vegetation types. This province has a mean annual precipitation of 1,200 to $2,000 \mathrm{~mm}$, with a pronounced dry season from May to September, a mean annual temperature from 21 to $25^{\circ} \mathrm{C}$ and a tropical climate (Cabrera \& Willink 1980). Most of the cerrado consists of seasonal savannas where corridors of mesophytic evergreen forests occur along the rivers (gallery forests) (Joly et al. 1999). Some physiognomic forms of savanna can be recognized in the cerrado vegetation, such as 'campo limpo' (grassland), 'campo sujo' (wood savanna), 'cerrado sensu stricto' (savanna), 'cerradão' (woodland), and 'campo rupestre'.

This province shows the highest number of native species of Crotalaria, with seven species and one subspecies restricted to this area. Among them, C. flavicoma has the highest frequency in cerrado, while some species have a very restricted distribution, as C. irwinii, C. rufipila and C. goiasensis.

The Crotalaria species occurs in all physiognomy types of savanna but some are restricted to a single location. $C$. irwinii is a rare species, with two collections, and it occurs in the border of gallery forests and outcrops and rocky slopes. C. goiasensis has been recorded only in the surroundings of the Serra dos Pirineus (GO), occurring on highlands , gallery forests and forest margins, from 900 to $1,200 \mathrm{~m}$. Crotalaria rufipila is an occasional species restricted to 'campo rupestre' in the Serra do Cipó and Serra da Piedade (MG).

The Paranaense province occupies areas from southern São Paulo to northern Rio Grande do Sul, between $18^{\circ} \mathrm{S}$ and $30^{\circ} \mathrm{S}$, with a dominance of Araucaria angustifolia (Bert.) O. Kuntze forests mixed with open vegetation. This province has a mean annual precipitation of 1,500 to $2,000 \mathrm{~mm}$, a mean annual temperature between 16 and $22^{\circ} \mathrm{C}$ and an essentially warm-temperate or subtropical climate (Cabrera \& Willink 1980). There are no restricted species in this province, but $C$. hilariana is a widespread species found on the highlands of Rio Grande do Sul, Santa Catarina and Paraná states. This species shows a phytogeographical distribution pattern similar to species of some temperate genera of Leguminosae, being limited to the south of the Tropic of Capricorn (Flores \& Miotto 2005).

The Atlantic province occupies Brazilian coast between $7^{\circ} \mathrm{S}$ and $30^{\circ} \mathrm{S}$, including 'restinga', or coastal vegetation and a small proportion of highland open vegetation. This province has a mean annual precipitation higher than 2,000 $\mathrm{mm}$, a mean annual temperature between 19 and $25^{\circ} \mathrm{C}$ and a tropical climate (Cabrera \& Willink 1980). In this province, Crotalaria vitellina is found occurring associated to restinga vegetation, coastal hillsides and adjacent sandy dune along most of theBrazilian coast. On the other hand, C. clausseni is endemic in highlands above 1,000 ms.m. of Serra da Bocaina (São Paulo state).

In Brazil, Amazonian province occupies the north between $4^{\circ} \mathrm{N}$ and $18^{\circ} \mathrm{S}$. Its climate is warm and humid, an average rainfall between 2,000 and 2,600 mm evenly distributed through the year and a mean annual temperature around $26^{\circ} \mathrm{C}$ (Cabrera \& Willink 1980). Despite Amazonian province being characterized by the presence of rainforest, there are isolated areas of cerradolike vegetation in northern (Amapá and Roraima states) and southern areas. In this province Crotalaria species are found in cerrado-like vegetation, disturbed or associated to course of river open areas. In Brazil, Crotalaria nitens is restricted to this province; it is widespread in Neotropics from North America to northern South America and its southern limit of distribution is northern of Mato Grosso state and Bolivia. This species occurs in open fields or 'capoeiras de terra firme' and also in border of 'mata de terra firme' on clay soils.

Caatinga province occupies the northern of Minas Gerais state and the greatest part of northeastern Brazil, from Bahia to Ceará and Piauí in part between $3^{\circ} \mathrm{S}$ and $15^{\circ} \mathrm{S}$. It shows a semiarid or arid climate with vegetational formations as forest like, arboreal, park, 
gramineous-woody, and ecological tension areas with cerrado to west and with Atlantic forest to east (Veloso et al. 1991). This province has a mean annual precipitation of 400 to 750 $\mathrm{mm}$ and a mean annual temperature between 26 and $27^{\circ} \mathrm{C}$ (Cabrera \& Willink 1980). Rainfall is unevenly distributed and the dry season (May-November) is pronounced and long. Crotalaria brachycarpa and C. bahiaensis are endemic in this province. $C$. brachycarpa is represented by two collections, of which one is the holotype. Moreover, it can be considered extinct because it has been not collected since 1907. C. bahiaensis is usually found in cerrado and cerrado transition to caatinga, on shallow rocky soils. Besides, $C$. harleyi and $C$. holosericea are widely found in areas of caatinga and transition cerrado-caatinga vegetation in Caatinga province. $C$. harleyi occurs only in Bahia state where it is restricted to areas of cerrado and caatinga on sandy soils above 800-1800 ms.m., near to Chapada Diamantina. C. holosericea has a wide distribution in northeastern region of Brazil in areas of cerrado, caatinga and some sites of the coast. This species is found in the border gallery forest and disturbed areas.

The remaining provinces, which have smaller areas in Brazil, concentrated a low number of Crotalaria species. In Brazil, the Chaqueña province is restricted to the extreme western edge around Corumbá (Mato Grosso do Sul state) near the $22^{\circ} \mathrm{S}$, but it occupies extra Brazilian areas of northern Argentina, western Paraguay and southeastern Bolívia (Prado 1993). This province has average rainfalls between 500 and $1,200 \mathrm{~mm}$, a mean annual temperature of 20 to $23^{\circ} \mathrm{C}$ and a deciduous xeromorphic vegetation (Cabrera \& Willink 1980). Crotalaria incana, C. laeta, C. maypurensis, C. sagittalis and $C$. stipularia have been collected in Corumbá vicinity, and no one of which is endemic to this province. In Guayana and Pampeana provinces only three and two species, respectively, are registered and no one is endemic to these provinces.

In Brazil, Pampeana province occupies southern Rio Grande do Sul state between $28^{\circ} \mathrm{S}$ and $33^{\circ} \mathrm{S}$ where there are fields with a lower grass cover showing a dominant herbaceous physiognomy associated with forest pocket into wetter areas along rivers margins (Cabrera \& Willink 1980, Joly et al. 1999). This province has a mean annual precipitation of 600 to $1.200 \mathrm{~mm}$, a mean annual temperature between 13 and $17^{\circ} \mathrm{C}$ and a warm-temperate climate (Cabrera \& Willink 1980). In this province, Crotalaria tweediana has a wide distribution and only few populations of $C$. hilariana occur. In Brazil, C. tweediana is found in rocky soils and on the top of mountains; it is restricted to south Brazil but its distribution extends to Argentina, Paraguay and Uruguay occupying four provinces: Chaquenha, Paranaense, Pampeana and Espinal.

Espinal province occupies an inexpressive portion in Rio Grande do Sul state, between $31^{\circ} \mathrm{S}$ and $30^{\circ} \mathrm{S}$. It is characterized by the presence of a dry forest, an average rainfalls between 340 and $1.170 \mathrm{~mm}$ and an average temperature of 15 to $20^{\circ} \mathrm{C}$ (Cabrera \& Willink 1980). In Brazil none of Crotalaria species have been already recorded, but three species are found in areas of this province in Argentina: $C$. stipularia, $C$. incana and $C$. tweediana (Gómez-Sosa 2000). The absence of Crotalaria species in the Brazilian portion of Espinal province may be explained by its restricted area in Brazil or might be due an artifact of low collecting effort in this region (Flores \& Miotto 2005).

Crotalaria species are represented in all Brazilian Regions, prevailing in southeast, central and part of northeastern regions, where they are found in open native vegetation, mainly comprising cerrado and coastal vegetation (Fig. 5). On the other hand, the low frequency of Crotalaria species in Amazon basin and extreme south regions may be associated with the predominance of rain forests and occurrence of a temperate climate, respectively.

Central and southeast Brazil have a predominance of cerrado vegetation, mainly in Minas Gerais and Goiás states, in which the highest number of Crotalaria species are found in Brazil (19 spp. each). In the northeast, Bahia state concentrates numerous species of the genus (ca. 15), of which two are endemic. 
This state has the major area in Northeast Region and possesses a great diversity of vegetation kinds, like cerrado, caatinga and Atlantic forest. It may explain the large number of Crotalaria species in this state. Moreover, the family Leguminosae was very collected for the preparation of Legumes of Bahia (Lewis 1987).

The high altitude is an important factor to the distribution of Crotalaria species in Brazil. The largest number of species is found in three areas with high altitudes (among 800-2,000 m) in central and southern Brazil. Two of these areas are localized in areas of cerrado, mainly in Goiás and Minas Gerais states, and the third one in the Atlantic forest in São Paulo, Rio de Janeiro and Minas Gerais states (Fig. 5). The first two regions are situated in Serra Geral de Goiás and Chapada dos Veadeiros (Goiás state), and in the Espinhaço Range (Minas Gerais state). Both regions concentrate 15-16 species of Crotalaria, which have the most important occurrence in campo rupestre, where C. rufipila, $C$. irwinii and $C$. goiasensis are only found in these areas.

The campo rupestre forms a mosaic of related vegetation communities under the control of local topography, microclimatic influences and the nature of the substrate (Giulietti \& Pirani 1988). The flora of campos rupestres has an elevated number of endemic taxa because of your isolated position on the top of the mountains. These mountain areas are distinct by different ecological conditions extant in lowlands, which operate as barrier for the migration (Harley 1995).

The third region of major species diversity (14 species) of the genus in Brazil is localized in Serra da Mantiqueira and Serra do Mar in São Paulo, south of Rio de Janeiro and the plateau south of Minas Gerais states. In this region, Crotalaria species mainly occurr at high elevations (campos de altitude), where $C$. claussenii is only found in Serra da Bocaina in Serra do Mar. The 'campo de altitude' is found on the top of woodland mountains above $1,500 \mathrm{~m}$ high and its physiognomy is characteristic of areas with a high degree of outcropping and reduction of soil depth with low forests bordering this formation (Lima \& Guedes-Bruni 1997).

In conclusion, the main factors that have influence on the species distribution of Crotalaria in Brazil are climate, vegetation types, and altitude. The species are concentrated in regions with tropical climate, especially in savanna vegetation at high altitudes. The geographical distribution of species in Brazil shows that Serra Geral de Goiás, Chapada dos Veadeiros, Espinhaço Range - in Central Brazil, and Serra da Mantiqueira and Serra do Mar - in southeast Brazil, are the centers of diversity of the genus in Brazil.

Cerrado province shows the greatest richness of species as well as the major number of restricted and endemic species, mainly in areas of campos rupestres. This fact can be explained by the great environmental diversity in this region, where heterogeneous vegetation types can be found, mainly in the areas of campos rupestres, which have a great degree of endemism.

Endemic Crotalaria taxa are concentrated mainly in areas of campos rupestres in Espinhaço Range (C. rufipila, C. martiana subsp. martiana, $C$. harleyi) and mountain ridges of Goiás (C. irwinii, C. goiasensis), where they generally are confined to one or two mountains. These areas present similar geological, physical and climatic features (Giulietti \& Pirani 1988) with campos rupestres interrupted by patches of cerrado and gallery forest. These associations of open areas and forest margin, wet or dry soils, and high elevations seem to be of great importance for speciation of the genus in Brazil. Studies on genetic diversity using molecular procedures and breeding systems should prove to be interesting and informative for understanding of species boundaries and processes of speciation of Brazilian species of Crotalaria.

\section{ACKNOWLEDGMENTS}

We are grateful to Rodrigo Schütz Rodrigues for his encouragement and suggestions. This paper is a part of a $\mathrm{PhD}$ thesis developed by A.S. Flores at the 'Programa de Pós-Graduação em Biologia Vegetal' of the Institute of Biology, 
Unicamp, which was supported by a grant from the Fundação de Amparo à Pesquisa do Estado de São Paulo (FAPESP proc. 00/11674-2).

\section{Literature Cited}

Bisby, F. A. \& Polhill, R. M. 1973. The role of taximetrics in angiosperm taxonomy II. Parallel taximetric and orthodox studies in Crotalaria L. New Phytologist 72: 727-742.

Cabrera, A. L. \& Willink, A. 1980. Biogeografia de America Latina. $2^{\mathrm{a}}$ ed. OEA, Washigton, $117 \mathrm{p}$.

Flores, A. S. 2004. Taxonomia, números cromossômicos e química das espécies de Crotalaria L. (Leguminosae, Papilionoideae) no Brasil. Tese de Doutorado. Universidade Estadual de Campinas, Campinas, 201p.

Flores, A. S. \& Miotto, S. T. S. 2005. Aspectos fitogeográficos das espécies de Crotalaria L. (Leguminosae-Faboideae) na Região Sul do Brasil. Acta Botanica Brasilica 19(2): 245-249.

Flores, A. S. \& Tozzi, A. M. G. A. 2005. A new species of Crotalaria (Leguminosae, Papilionoideae) from southeastern Brazil. Novon 15: 418-420.

Giulietti, A. M. \& Pirani, J. R. 1988. Patterns of geographic distribution of some plant species from the espinhaço range, Minas Gerais and Bahia, Brazil. In: Heyer W.R., Vanzolini P. E. (eds.). Proceedings of a workshop on neotropical distribution patterns. Rio de Janeiro: Academia Brasileira de Ciências 39-69.

Gómez-Sosa, E. 2000. Las especies argentinas de Crotalaria (Leguminosae-Crotalarieae): novedades, descripciones y clave. Gayana Botanica 57(1): 67-87.

Harley, R. M. 1995. Introduction. In: B. L. Stannard (ed.). Flora do Pico das Almas - Chapada Diamantina - Bahia, Brazil. Royal Botanic Gardens, Kew, 853p.

Holmgren, P.K., Holmgren, N.H. \& Barnett, L. C. 1990. Index Herbariorum Part I: The Herbaria of the world. New York Botanical Garden, New York, 691p.
Joly, C. A.; Aidar, M. P. M.; Klink, C. A.; McGrath, D. G.; Moreira, A. G.; Moutinho, P.; Nepstad, D. C.; Oliveira, A. A.; Pott, A.; Rodal, M. J. N. \& Sampaio, E. V. S. B. 1999. Evolution of the Brazilian phytogeography classifications systems: implications for biodiversity conservation. Ciência e Cultura 51(5/6): 331-348.

Lewis, G. P. 1987. Legumes of Bahia. Royal Botanic Gardens, Kew. Pp. 1-369.

Lima, H. C. \& Guedes-Bruni, R. R. 1997. Introdução. In: Lima, H. C. \& GuedesBruni, R. R. (eds.). Serra de Macaé de Cima: diversidade florística e conservação em Mata Atlântica. Instituto de Pesquisas Jardim Botânico do Rio de Janeiro, Rio de Janeiro. Pp. 13-25.

Palomino, G. \& Vásquez, R. 1991. Cytogenetic studies in Mexican populations of species of Crotalaria L. (LeguminosaePapilionoideae). Cytologia 56: 343-351.

Polhill, R. M. 1968. Miscellaneous notes on African species of Crotalaria. II. Kew Bulletin 22: 169-348.

Polhill, R. M. 1982. Crotalaria in Africa and Madagascar. Royal Botanic Gardens, Kew, 389p.

Polhill, R. M.; Tozzi, A. M. G. A. \& Flores, A. S. 2001. Crotalarieae. In: Bisby, F. A.; Zaruchi, J. L.; Roskov, Y. R.; Schrire, B. D.; Heald, J.; White, R .J. (eds.). International Legume Database \& Information Service (ILDIS). Legumes of the world - CD-Rom e http:/ /www.ildis.org

Prado, D. E. 1993. What is the Gran Chaco vegetation in South America? I. A review. Contribution to the study of flora and vegetation of the Chaco. V. Candollea 48: 145-172.

Senn, H. A. 1939. The North American species of Crotalaria. Rhodora 41: 317-367.

Veloso, H. P.; Rangel Filho, A. L. R. \& Lima, J. C. A. 1991. Classificação da vegetação brasileira, adaptada a um sistema universal. MEFP/IBGE/DRNEA, 123p.

Windler, D. R.; Adler, L. \& Skinner, S. G. 1992. Crotalaria incana var. grandiflora (Leguminosae): a new variety from South America. Phytologia 73(2): 155-158. 